\title{
Tay-Sachs Disease with Altered $\beta$-Hexosaminidase B: A New Variant?
}

\author{
TORU MOMOI, ${ }^{(30)}$ MASAKATSU SUDO, KENICHI TANIOKA, AND YASUJI NAKAO \\ Department of Pediatrics, School of Medicine, Kyoto University, Kyoto, Japan \\ SHINICHI HARUKI \\ Department of Pediatrics, Himeji National Hospital, Himeji, Japan
}

\section{Summary}

A 2.5-year-old Japanese girl who showed signs and symptoms compatible with classic Tay-Sachs disease and had altered $\beta$ hexosaminidase $B$ and $I_{1}$ as well as completely deficient $\beta$ hexosaminidase $A$ activity is reported herein.

Heat treatment of the patient's serum and leukocyte samples showed the existence of $13.5-27.3 \%$ and $35.7 \%$ of the heatlabile component of $\beta$-hexosaminidase, respectively, such is usually considered to correspond to $\beta$-hexosaminidase $A$. The absence of $\beta$-hexosaminidase $A$ activity was confirmed by DEAE-cellulose column chromatography and cellulose acetate paper electrophoresis. The patient's serum $\beta$-hexosaminidase also contained a significant amount of acid pH-labile components. The effects of buffer concentrations on the activities of total and heat-labile components of the serum $\beta$-hexosaminidase of the patient differed from those of the control subjects.

Heat treatment of the each component of serum $\beta$-hexosaminidase which had been separated by DEAE-cellulose column chromatography showed that $\beta$-hexosaminidase $B$ and $I_{1}$ in the serum from this patient were heat labile as compared with those from the control subjects, and the other component $I_{2}$ was less heat labile at $50^{\circ}$ for $3 \mathrm{~h}$.

There were no differences in the $k_{m}$ values of $\beta$-hexosaminidase $B, I_{1}$, and $I_{2}$ for the synthetic substrate 4 -methylumbelliferyl $N$-acetyl- $\beta$-D-glucosaminide before and after heat treatment at $50^{\circ}$ for $3 \mathrm{~h}$ among the reported patient, another patient with classic Tay-Sachs disease, and a normal infant.

\section{Speculation}

In prenatal diagnosis of such patients as reported herein, it will be necessary to confirm the absence of $\beta$-hexosaminidase $A$ in amniotic fluid and/or amniotic fluid cells by methods other than the heat-inactivation method, e.g., electrophoresis or ionexchange column chromatography.

Tay-Sachs disease (TSD) is a lysosomal storage disease inherited in an autosomal recessive manner. The gene frequency is extremely high in the Jewish population, but sporadic cases have been reported from various other populations including the Japanese.

In 1969, Okada and O'Brien (13) did starch-gel electrophoresis studies and found that one of two isozymes of $N$-acetyl $\beta$ D-hexosaminidase (Hex), Hex $A$, was absent in brain, liver, kidney, skin, cultured skin fibroblasts, blood plasma, and leukocytes from TSD patients. In 1970, O'Brien et al. (11) reported a heat-inactivation method for serum Hex A determination with the synthetic substrate 4 -methylumbelliferyl $N$-acetyl- $\beta$-Dglucosaminide and its application to the detection of TSD heterozygotes and homozygotes. Since that time, the heat-inactivation method has been used for the detection of TSD patients, its carriers, and patients with partial Hex A deficiency. Patients with partial Hex A deficiency are distinguishable from those with classic. TSD as the onset is later and the course milder (2, $14,23,28)$.

We encountered a Japanese girl who showed signs and symptoms compatible with classic TSD. Hex A activities in serum samples, as detected by the heat-inactivation method, revealed partial deficiency in this isozyme. As there is apparently no documentation concerning classic TSD with partial Hex A deficiency, we investigated the nature of the heat lability of Hex in our patient and the findings are reported herein.

\section{CASE REPORT}

In August 1973, a healthy primipara gave birth to a girl (YI) weighing $3210 \mathrm{~g}$. The pregnancy and delivery were uneventful and both parents were Japanese and first cousins. Apparently no other family members had the same disorder as this patient.

The child developed normally until 6 months of age when she appeared unresponsive to her surroundings. At 7 months of age, she was pointed out to have cherry red spots, and since that time she deteriorated gradually both mentally and physically. The serum Hex assay by the heat-inactivation method performed at that time showed about $20 \%$ of residual Hex A activity. General convulsions first occurred at the age of 18 months and have since increased despite anticonvulsant therapy. The rectal biopsy, performed with the informed consent of the parents when the child was 20 months of age, revealed numerous membranous cytoplasmic bodies in the myenteric plexus. Results of the electrophysiologic examinations of the patient's eyes have been reported elsewhere (7). EEG recorded at 20 months of age showed diffuse organic dysfunction with multiple spike foci. Hepatosplenomegaly was absent but serum LDH and GOT levels were markedly elevated.

On the last visit to our clinic in March 1976, she showed little spontaneous motor activity and no exaggerated extension response to sound. Muscle hypotonia and spasticity of limbs were remarkable. Head circumference had increased to $2.5 \sigma$ over the mean value.

\section{MATERIALS AND METHODS}

\section{SAMPLES}

Serum samples were obtained from the patient, $Y I$, and a patient with classic TSD who showed typical heat stability of serum Hex activity as determined by the heat inactivation method. Serum samples from both parents of $Y I$ and a classic TSD patient, and from adults and infants who were apparently free from any inherited disorders were also studied. These samples were examined immediately or stored at $-20^{\circ}$ until use.

Leukocytes were isolated from heparinized venous blood of 
the patient, $Y I$, a classic TSD patient, and control adults. One volume of venous blood was mixed with 2 vol $3 \%$ dextran (mol wt 200,000 ) in $0.9 \% \mathrm{NaCl}$ solution, and allowed to stand at room temperature for $20-30 \mathrm{~min}$. The supernatant containing leukocytes was then separated and washed twice with $0.9 \%$ $\mathrm{NaCl}$ solution. Contaminating red blood cells were destroyed by adding 3 vol water and mixing gently for $90 \mathrm{sec}$, then the osmolarity was recovered by adding 1 vol of $3.6 \% \mathrm{NaCl}$ solution. The leukocyte pellet obtained by centrifugation was diluted with water to the protein concentrations of $1.0-2.0 \mathrm{mg}$ / $\mathrm{ml}$, then homogenized, frozen, and thawed several times and centrifuged at $1000 \times g$ for $10 \mathrm{~min}$. The supernatant was used immediately for the present studies concerning Hex. Protein concentrations of the supernatant were determined by the method of Lowry et al. (9).

All samples were obtained with the informed consent of patients and/or their parents.

\section{ENZYME ASSAYS}

Hex activities in serum and leukocyte samples were determined by the method of O'Brien et al. (11) using 4-methylumbelliferyl $N$-acetyl- $\beta$-D-glucosaminide (Nakarai Chemicals Ltd., Japan) as a substrate.

$\beta$-Glucosidase and $\beta$-galactosidase in leukocyte homogenates from the patient, $Y I$, a classic TSD patient, and control subjects were also determined fluorometrically using 4-methylumbelliferyl $\beta$-D-glucoside $(1 \mathrm{mM})$ and -galactoside $(2 \mathrm{mM})$ as substrates (Nakarai Chemicals Ltd.), respectively. Reaction mixtures contained $20 \mu$ l leukocyte homogenate, $20 \mu$ l citratephosphate buffer $(0.1 \mathrm{M}$ with respect to a citric acid, $\mathrm{pH} 4.0$ and 5.5 for $\beta$-glucosidase, or $\mathrm{pH} 4.0$ for $\beta$-galactosidase), and $50 \mu$ l substrate solution.

\section{MIXING EXPERIMENTS}

Serum from the patient was mixed with the same volume of serum samples from a classic TSD patient and a control infant, respectively, and the total and heat-labile components of Hex were determined by the heat-inactivation method.

\section{PH ACTIVITY CURVES}

Total serum Hex activities-with a $\mathrm{pH}$ ranging from 3.0-7.0 were determined with citrate-phosphate buffers $(0.04 \mathrm{M}$ citric acid was mixed with $0.08 \mathrm{M}$ dibasic sodium phosphate).

\section{ACID pH INACTIVATION}

Acid pH-labile components of serum Hex were determined by the method of Saifer and Rosenthal (19) with $0.5 \mathrm{M}$ glycine$\mathrm{HCl}$ buffer, $\mathrm{pH} 2.8$.

\section{EFFECTS OF BUFFER CONCENTRATIONS ON TOTAL AND HEAT.} LABILE COMPONENTS OF SERUM HEX ACTIVITIES

These effects were examined using $0.01,0.04,0.08$, and $0.16 \mathrm{M}$ citrate-phosphate buffers, $\mathrm{pH} 4.4$ (concentrations as a citric acid). Heat-inactivation and incubation procedures were the same as those described by O'Brien et al. (11) except for the buffer concentrations used.

\section{$\mathrm{K}_{\mathrm{m}}$ VALUES}

$\mathrm{K}_{\mathrm{m}}$ values for 4-methylumbelliferyl $N$-acetyl- $\beta$-D-glucosaminide of serum and leukocyte samples were determined by the method of Lineweaver and Burk (8). $K_{m}$ values of the each component of serum Hex $\left(B, I_{1}, I_{2}\right.$, and $\left.A\right)$ before and after heat treatment at $50^{\circ}$ for $3 \mathrm{~h}$ were also determined by the same method.

\section{CELLULOSE ACETATE PAPER ELECTROPHORESIS}

Electrophoresis was run in accordance with the method of Poenaru and Dreyfus (15) with modifications. Details of the procedures have been described elsewhere (24).

\section{DEAE-CELLULOSE COLUMN CHROMATOGRAPHY}

The ion-exchange column chromatography was performed by the method of Price and Dance (16) with modification using Whatman DE 52 (Whatman Biochemical Ltd., England) as a stationary phase.

A serum sample $(0.1 \mathrm{ml})$, stored at $-20^{\circ}$ for 3 months, was diluted 5-fold with $0.01 \mathrm{M}$ sodium phosphate buffer, $\mathrm{pH} 7.0$, and applied to a column $(1 \times 6 \mathrm{~cm})$ without predialysis; $2 \mathrm{ml}$ fractions were obtained.

For the $\mathrm{K}_{\mathrm{m}}$ determination and heat-inactivation studies of the each component of serum Hex, $1 \mathrm{ml}$ serum sample was applied to the column $(1.5 \times 11.0 \mathrm{~cm})(24)$. The column fractions $(5-\mathrm{ml}$ fraction) constituting each peak of Hex activity were pooled, then dialyzed against water overnight at $4^{\circ}$ and lyophilized. After lyophilization, each component was diltued with $0.04 \mathrm{M}$ citrate-phosphate buffer, $\mathrm{pH} 4.4$ (concentration as a citric acid).

All experiments were run in duplicate on samples from the patient, $Y I$, in parallel with those from a classic TSD patient and control subjects, and sometimes with obligate heterozygotes.

\section{RESULTS}

Heat-labile components of serum Hex from the patient, $Y I$, a classic TSD patient, their parents, and adult and infant control subjects are shown in Table 1 . These components in serum samples from the patient, $Y I$, obtained at various intervals were $13.5-27.3 \%$ of the total activities as compared to those of $0-$ $5.9 \%$ in a classic TSD patient, and $55.6-77.6 \%$ in control subjects. Although serum samples from three obligate heterozygotes except those from YI's mother showed 33.8-48.3\%, four samples from $Y I$ 's mother showed $49.5-54.4 \%$. Although total and heat-labile components of serum Hex in one person varied in their activities from sample to sample obtained at different occasions, no overlaps in heat-labile components expressed as a percentage of total activities were observed between samples from the patient, $Y I$, a classic TSD patient, obligate heterozygotes, and normal control subjects.

The time course of heat inactivation of serum Hex is shown in Figure 1. The serum Hex activity of $Y I$ decreased linearly during a $3-\mathrm{h}$ heat treatment at $50^{\circ}$. Figure 2 shows the time course of heat inactivation of Hex in leukocytes. Leukocyte Hex activity from the patient, $Y I$, decreased linearly as in the case of serum Hex and the activity of heat-labile component

Table 1. Heat-labile components of serum Hex

\begin{tabular}{llcccc}
\hline & & & & \multicolumn{2}{c}{ Controls } \\
\cline { 4 - 6 } & \multicolumn{1}{c}{ Y1 } & $\begin{array}{c}\text { Classic } \\
\text { TSD }\end{array}$ & Heterozygotes & Infants & 11 \\
$\begin{array}{l}\text { No. of samples } \\
\begin{array}{l}\text { \% of total } \\
\quad \text { activity }\end{array}\end{array}$ & 13 & 6 & 13 & 18 & \\
Mean & & & & & \\
Range & 18.8 & 2.9 & 47.5 & 65.5 & 67.4 \\
\end{tabular}




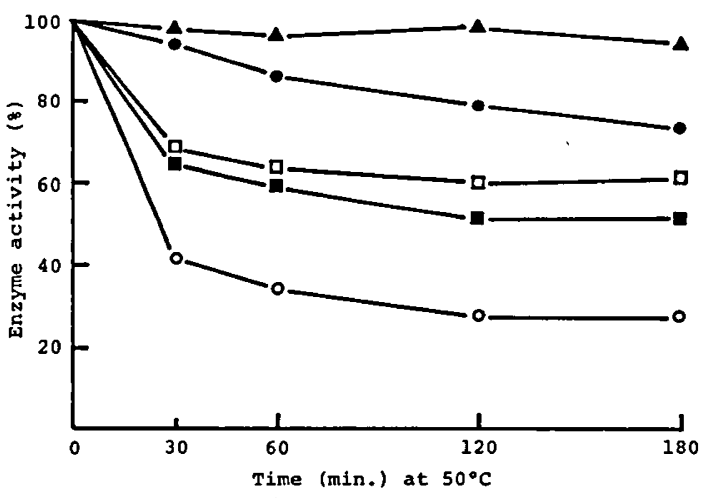

Fig. 1. The time course of heat inactivation of serum Hex from the patient, $Y I,(\bullet)$, a classic TSD patient $(\boldsymbol{\Delta})$, mother of $Y I(\mathbb{\nabla})$, mother of a classic TSD patient $(\square)$, and an adult control subject (O). Enzyme activities before heat inactivation are expressed as $100 \%$.

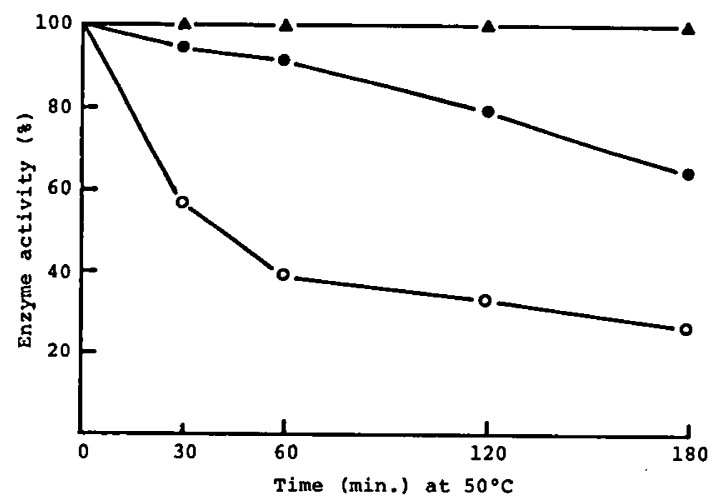

Fig. 2. The time course of heat inactivation of leukocyte Hex from the patient, $Y I,(\bullet)$, a classic TSD patient $(\Delta)$, and an infant control subject $(O)$. Enzyme activities before heat inactivation are expressed as $100 \%$.

after $3 \mathrm{~h}$ at $50^{\circ}$ was $35.7 \%$ of the total Hex activity as compared to $0 \%$ and $73.6 \%$ from a classic TSD patient and an infant control, respectively. The presence of $0.1 \%$ of bovine serum albumin in reaction mixtures for heat treatment of leukocytes had no effect on the total and heat-labile components of Hex activities.

Mixing experiments were carried out to determine the presence of factors which would influence the heat stability of the patient's serum Hex. The predicted and actual values of the heat-labile component in mixed samples were practically the same and inhibitory factors were not detected in the patient's serum.

Acidic pH-labile and heat-labile components of serum Hex were determined on the same samples from the patient, $Y I$, a classic TSD patient, and an infant control subject. Table 2 shows that the patient's serum contained a significant amount of acidic pH-labile components of Hex.

The optimal $\mathrm{pH}$ of serum Hex of the patient, $Y I$, was 4.24.4 , and there was no difference from the optimal $\mathrm{pH}$ of a classic TSD patient, obligate heterozygotes, and infant control subjects.

The effects of buffer concentrations on the activities of the total and heat labile components of serum Hex of the patient, $Y I$, a classic TSD patient, and an infant control subject are shown in Figure 3. Although the activity of heat-labile components of serum Hex from a control subject was maximal at 0.04 $M$, that of the patient, $Y I$, and a classic TSD patient increased as the buffer concentration increased. Serum Hex from the patient, $Y I$, was more intense in this increment: the activity of heat-labile components of YI's serum Hex was as much as $34.9 \%$ of the total at a buffer concentration of $0.16 \mathrm{M}$.
Cellulose acetate paper electrophoresis (Fig. 4) showed two bands in serum samples from the patient, $Y I$, and a classic TSD patient corresponding to $\mathrm{Hex} B$ and $\mathrm{Hex} \mathrm{I}_{1}+\mathrm{I}_{2}$ from the cathode to the anode as compared to three bands in those from control subjects with the additional most anodic band corresponding to Hex A (24). Leukocyte samples showed one band in the patient, $Y I$, and a classic TSD patient and two bands in control subjects. Electropherograms of serum and leukocyte

Table 2. Acidic pH-labile and heat-labile components of serum Hex

\begin{tabular}{lcc}
\hline & \multicolumn{2}{c}{ \% of total activity } \\
\cline { 2 - 3 } & $\mathrm{pH}$ inactivation & Heat inactivation \\
\hline YI & 8.3 & 22.3 \\
Classic TSD & 1.8 & 3.9 \\
Control & 55.2 & 58.8 \\
\hline
\end{tabular}

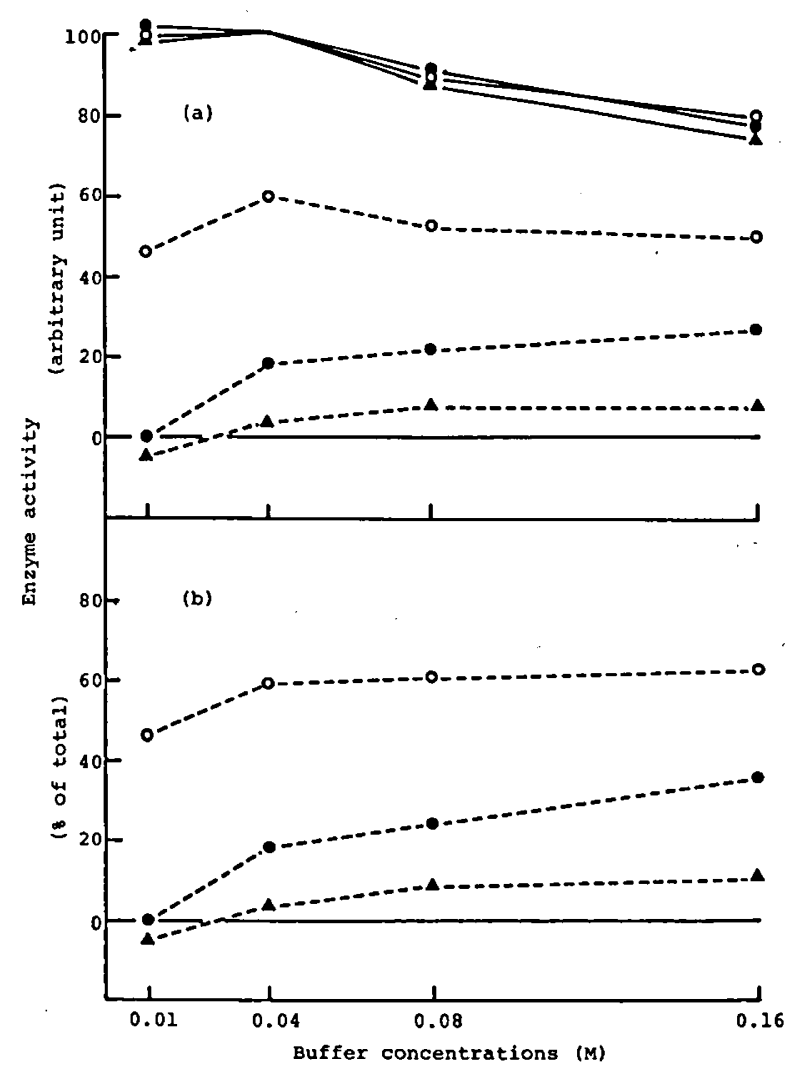

Fig. 3. The effects of buffer concentrations on the activities of the total (-) and the heat-labile (- - ) components of serum Hex of the patient, $Y I,(\bullet)$, a classic TSD patient $(\boldsymbol{\Lambda})$, and an infant control subject $(O)$. The total activities at the buffer concentration of $0.04 \mathrm{M}$ are expressed as 100 (a); the heat-labile components are expressed as percentage of the total (b).

$(+)$

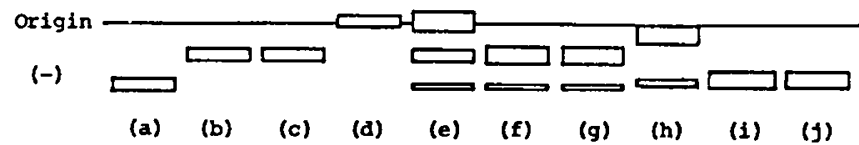

Fig. 4. Cellulose acetate paper electrophoresis of serum and leukocyte Hex. (a)-(d); Hex B, $I_{1}, I_{2}$, and A, respectively, from a normal adult serum which was separated by DEAE-cellulose column chromatography. (e)-(g); serum Hex from a normal infant, the patient, $Y I$, and a classic TSD patient, respectively. (h)-(j); leukocyte Hex from a normal adult, the patient, $Y I$, and a classic TSD patient, respectively. 
Hex from the patient, $Y I$, and a classic TSD patient revealed no differences, both being deficient in Hex A activities.

DEAE-cellulose column chromatography of control serum samples showed four isozymes (Hex $B, I_{1}, I_{2}$, and A) (Fig. 5) as reported previously $(16,24,27)$. Serum samples from $Y I$ and a classic TSD patient were lacking in Hex $A$ and had increased Hex $\mathrm{I}_{2}$. The chromatograms of serum Hex of the patient, $Y I$, and a classic TSD patient were the same. There were no changes in elution profiles of YI's serum stored for 11 days to 5 months.

$\mathrm{K}_{\mathrm{m}}$ values for 4-methylumbelliferyl $N$-acetyl- $\beta$-D-glucosaminide of the total and each component of serum and the total leukocyte Hex were determined (Table 3). There were no differences in $\mathrm{K}_{\mathrm{m}}$ values among the samples from the patient, $Y I$, a classic TSD patient, and a control infant. Heat treatment at $50^{\circ}$ for $3 \mathrm{~h}$ had no effect on $\mathrm{K}_{\mathrm{m}}$ values of each component of serum Hex.

The time course of heat inactivation of each component of serum Hex which had been separated by DEAE-cellulose column chromatography is shown in Figure 6 . Hex $B$ and $I_{1}$ in serum from the patient, $Y I$, were different in heat stability from those of a classic TSD patient and a control subject; $50 \%$ decrease in activities of Hex B and $I_{1}$ had occurred in YI's serum after heat treatment at $50^{\circ}$ for $3 \mathrm{~h}$, whereas there was less than $18 \%$ decrease in the serum samples from a classic TSD patient and a control subject. This experiment was repeated on samples obtained at different occasions, and the results were essentially the same. Activities of other lysosomal enzymes, such as $\beta$-glucosidase and $\beta$-galactosidase in leukocyte
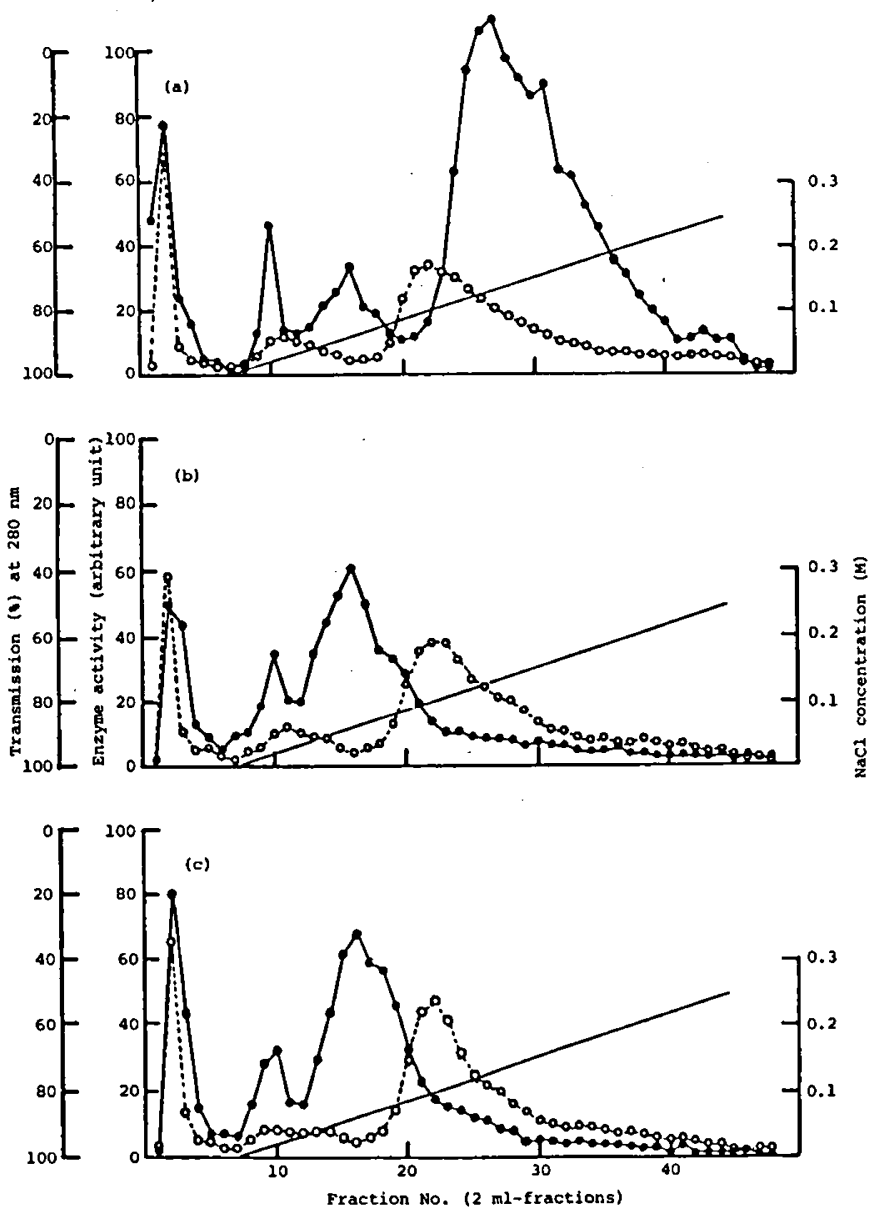

Fig. 5. DEAE-cellulose column chromatography of serum samples from a control infant (a), the patient, $Y I$, (b), and a classic TSD patient (c). Enzyme activity (-@) is expressed in an arbitrary unit. Protein concentration $\left(\mathrm{O}_{-}-\mathrm{O}^{-}\right)$is expressed as percentage of transmission at $280 \mathrm{~nm}$. Linear line $(-)$ indicates $\mathrm{NaCl}$ concentration $(\mathrm{M})$.
Table 3. $K_{m}$ values (millimolar concentration) of serum and leukocyte Hex for 4-methylumbelliferyl $N$-acetyl- $\beta$ - $D$ glucosaminide

\begin{tabular}{lcccccc}
\hline & \multicolumn{5}{c}{ Serum } & $\begin{array}{l}\text { WBC } \\
\text { total }\end{array}$ \\
\cline { 2 - 7 } & Total & $\mathrm{B}$ & $\mathrm{I}_{1}$ & $\mathrm{I}_{2}$ & $\mathrm{~A}$ & ( \\
& 0.67 & 0.65 & 0.51 & 0.52 & & 0.95 \\
YI & 0.62 & 0.53 & 0.59 & 0.57 & & 0.89 \\
Classic TSD & 0.75 & 0.55 & 0.55 & 0.55 & 0.80 & 0.95 \\
Control & & & & & &
\end{tabular}

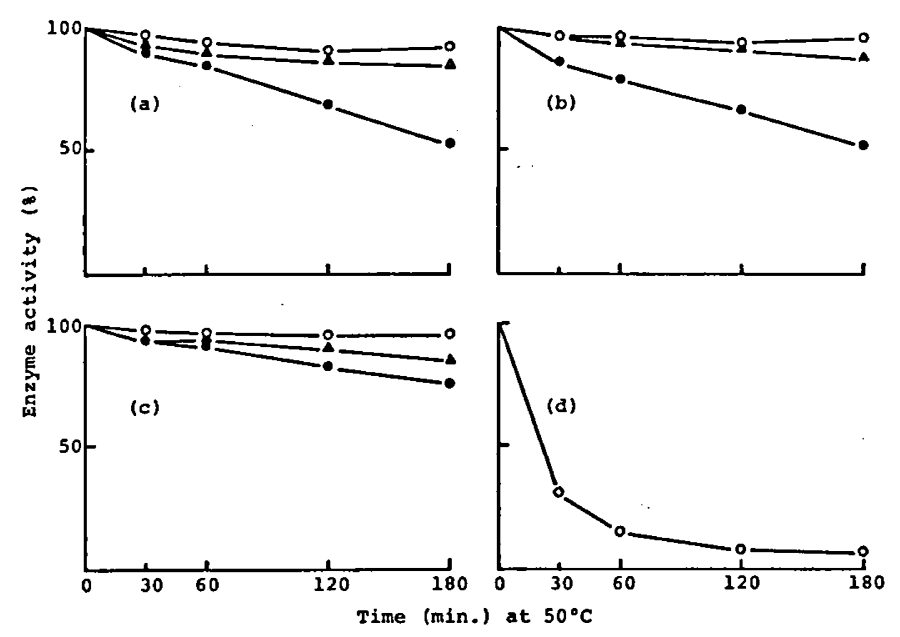

Fig. 6. The time course of heat inactivation of serum Hex B (a), $I_{1}$ (b), $I_{2}$ (c), and A (d) from the patient $Y I(\bullet)$, a classic TSD patient $(\boldsymbol{\Lambda})$, and an infant control subject $(O)$. The enzyme activities before heat inactivation are expressed as $100 \%$.

homogenates from the patient, $Y I$, were within the normal range.

\section{DISCUSSION}

Since Hex was found to be composed of two major isozymes, $A$ and $B$, and Hex $A$ activity was completely deficient in patients with TSD, $\mathrm{G}_{\mathrm{M}_{2}}$-gangliosidoses have been classified into three types $(12,20)$. These are Tay-Sachs disease (type 1 or variant $B$ ), deficient in Hex A, Sandhoff-Jatzkewitz disease (type 2 or variant $\mathrm{O}$ ), deficient in both Hex $\mathrm{A}$ and $\mathrm{B}$, and a juvenile $G_{M_{2}}$-gangliosidosis (type 3 ), partially deficient in Hex A.

In the enzyme assay, as the synthetic substrates $p$-nitrophenyl or 4-methylumbelliferyl derivatives of $N$-acetyl- $\beta$-D-glucosaminide and -galactosaminide have been made available, many samples were examined and mass screening for heterozygotes detection has been done $(3,17,18)$.

Recently, it has become apparent that there are variant types of Hex deficiency. These variants may be due to allelic mutation or double mutations in loci concerned with Hex isozymes $(3,5$, $10,20,21,25,26)$. Variant types which have been reported may be divided into three groups: (1) the enzyme activities are present to a natural substrate but absent to a synthetic one (5, $10,25),(2)$ the reversed condition as in the case of $(1)(3,20)$, and (3) non-uniform distribution of the enzyme in various tissues in a single person $(21,25,26)$.

Although the specimens used in our study were only serum and leukocytes and the natural substrate, $\mathrm{G}_{\mathrm{M}_{2} \text {-ganglioside, could }}$ not be used in the enzyme assays, the data from patient, $Y I$, was different from classic TSD patients as well as the variant cases reported up to date. The isozymes, Hex $B, I_{1}$, and $I_{2}$, were detected by ion-exchange column chromatography and cellulose acetate paper electrophoresis in the same manner as those from a classic TSD patient. But enzymatic studies on Hex of the patient, $Y I$, showed $(1)$ increased heat lability at $50^{\circ}$ for 
$3 \mathrm{~h},(2)$ increased acidic pH lability, and (3) characteristic changes in heat stability in various buffer concentrations.

The optimal $\mathrm{pH}$ of total Hex and $\mathrm{K}_{\mathrm{m}}$ values of the total and each component of Hex, however, did not differ from those of a classic TSD patient and control subjects.

The heat treatment study in each component revealed that heat lability of Hex in the patient, $Y I$, was localized in Hex B and $I_{1}$, and that Hex $I_{2}$ was less heat labile at $50^{\circ}$ for $3 \mathrm{~h}$.

Recent investigations suggest that $\mathrm{Hex}_{2}$ may be regulated in a somewhat different manner from Hex B and $I_{1}$, although these three isozymes have been regarded as a single group. The three isozymes have heat stability in common but it is well known that Hex $I_{2}$ is markedly increased in serum samples from TSD patients (16), pregnant women $(16,22,27)$, and diabetics (16). The increment of Hex $I_{2}$ in pregnant women and diabetics strongly suggests the presence of hormone-related regulations on this isozyme whereas the increment in TSD patients in whom Hex $A$ is absent suggests a close relationship between the regulation of $\mathrm{Hex}_{2}$ and $A$.

Some hypotheses have been advanced to explain mechanisms regulating the Hex isozymes. Beutler et al. (1) reported that Hex B was a tetramer composed of identical subunits and Hex A was also tetramer but was composed of two different kinds of subunits, one of which was common to that of Hex B. Gilbert et al. (6), on the other hand, postulated the structural independency of Hex B and A on the basis of cell hybridization studies. Hex $B$, as described by these authors, however, was the sum of Hex $B, I_{1}$, and $I_{2}$. Regulations and structures of each component of $B$ group $\left(B, I_{1}\right.$, and $\left.I_{2}\right)$ remain to be determined.

If the abnormalities in Hex $\mathrm{B}$ and $\mathrm{I}_{1}$ of the patient, $Y I$, are genetically linked, regardless of how Hex B and A are structurally dependent, they can hardly be explained without the occurrence of double mutations: in addition to the typical TSD gene, another mutation results in the abnormalities of Hex B and $I_{1}$. Although the activity of heat-labile component of serum Hex from the mother was somewhat higher than the activity from the other obligate heterozygotes, heat-inactivation studies of each component of serum Hex from YI's parents revealed no difference from those of normal adults and the homozygote and heterozygotes of classic TSD.

To clarify the genetic mechanisms, other methods for detecting abnormalities of Hex $\mathrm{B}$ and $\mathrm{I}_{1}$ in the patient, $Y I$, and her parents have to be devised.

\section{REFERENCES AND NOTES}

1. Beutler, E., Yoshida, A., Kuhl, W., and Lee, J. E. S.: The subunits of human hexosaminidase A. Biochem. J., 159: 541 (1976).

2. Brett, E. M., Ellis, R. B., Haas, L., Ikonne, J. U., Lake, B. D., Patrick, A. D., and Stephens, R.: Late onset $\mathbf{G}_{\mathbf{M}_{2}}$-gangliosidosis. Clinical, pathological, and biochemical studies on 8 patients. Arch. Dis. Childhood, 48: 775 (1973).

3. de Baecque, C. M., Suzuki, K., Rapin, I., Johnson, A. B., Whethers, D. L.,

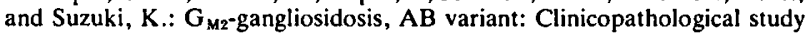
of a case. Acta Neuropathol., 33: 207 (1975).

4. Delvin, E., Pottier, A., Scriver, C. R., and Gold, R. J. M.: The application of an automated hexosaminidase assay to genetic screening. Clin. Chim. Acta, 53: 135 (1974).

5. Dreyfus, J. C., Poenaru, L., and Svennerholm, L.: Absence of hexosaminidase A and B in a normal adult. New Engl. J. Med., 292: 61 (1975).

6. Gilbert, F., Kucherlapati, R., Creagan, R. P., Murnane, M. J., Darlington,
G. J., and Ruddle, F. H.: Tay-Sachs' and Sandhoff's diseases: The assignment of genes for hexosaminidase $\mathrm{A}$ and $\mathrm{B}$ to individual human chromosomes. Proc. Nat. Acad. Sci. U. S. A., 72: 263 (1975).

7. Honda, Y., and Sudo, M.: Electroretinogram and visually evoked cortical potential in Tay-Sachs disease: A report of two cases. J. Pediat. Opthalmol. 13: 226 (1976).

8. Lineweaver, H., and Burk, D.: The determination of enzyme dissociation constants. J. Amer. Chem. Soc., 56: 658 (1934).

9. Lowry, O. H., Rosebrough, N. J., Farr, A. L., and Randall, R. J.: Protein measurement with the Folin phenol reagent. J. Biol. Chem., 193: 265 (1951).

10. Navon, R., Padeh, B., and Adam, A.: Apparent deficiency of hexosaminidase $A$ in healthy members of a family with Tay-Sachs disease. Amer. J. Hum. Genet., 25: 287 (1973).

11. O'Brien, J. S., Okada, S., Chen, A., and Fillerup, D. L.: Tay-Sachs disease. Detection of heterozygotes and homozygotes by serum hexosaminidase assay. New Engl. J. Med., 283: 15 (1970).

12. O'Brien, J. S., Okada, S., Ho, M. W., Fillerup, D. L., Veath, M. L., and Adams, K.: Ganglioside storage diseases. Fed. Proc., 30: 956 (1971).

13. Okada, S., and O'Brien, J. S.: Tay-Sachs disease: Generalized absence of a beta-D- $N$-acetylhexosaminidase component. Science, $165: 698$ (1969).

14. Okada, S., Veath, M.L., and O'Brien, J. S.: Juvenile $\mathrm{G}_{M_{2}}$ gangliosidosis: Partial deficiency of hexosaminidase A. J. Pediat., 77: 1063 (1970).

15. Poenaru, L., and Dreyfus, J. C.: Electrophoretic study of hexosaminidases. Hexosaminidase C. Clin. Chim. Acta, 43: 439 (1973).

16. Price, R. G., and Dance, N.: The demonstration of multiple heat stable forms of $N$-acetyl- $\beta$-glucosaminidase in normal human serum. Biochim. Biophys. Acta, 271: 145 (1972).

17. Rosenberg, D., and Cutler, R.: Tay-Sachs carrier detection by mechanized serum hexosaminidase assay. Clin. Chim. Acta, 53: 247 (1974).

18. Saifer, A., and Perle, G.: Automated determination of serum hexosaminidase $\mathrm{A}$ by $\mathrm{pH}$ inactivation for detection of Tay-Sachs disease heterozygotes Clin. Chem., 20: 538 (1974).

19. Saifer, A., and Rosenthal, A. L.: Rapid test for the detection of Tay-Sachs disease heterozygotes and homozygotes by serum hexosaminidase assay. Clin. Chim. Acta, 43: 417 (1973).

20. Sandhoff, K., Harzer, K., Wässle, W., and Jatzkewitz, H.: Enzyme alterations and lipid storage in three variants of Tay-Sachs disease. J. Neurochem. 18: 2469 (1971).

21. Spence, M. W., Ripley, B. A., Embil, J. A., and Tibbles, J. A. R.: A new variant of Sandhoff's disease. Pediat. Res., 8: 628 (1974).

22. Stirling, J. L.: Separation and characterization of $N$-acetyl- $\beta$-glucosaminidases $A$ and $P$ from maternal serum. Biochim. Biophys. Acta, 271: 154 (1972).

23. Suzuki, K., Suzuki, K., Rapin, I., Suzuki, Y., and Ishii, N.: Juvenile G $\mathbf{M}_{2}$ gangliosidosis: Clinical variant of Tay-Sachs disease or a new disease. Neurology, 20: 190 (1970).

24. Tanioka, K., Momoi, T., Nakao, Y., and Sudo, M.: Electrophoretic separation of $\beta$-hexosaminidase in human serum. Ann. Pediat. Jap., 23: 34 (1977).

25. Vidgoff, J., Buist, N. R. M., and O'Brien, J. S.: Absence of $\beta-N$-acetyl-Dhexosaminidase $A$ activity in a healthy woman. Amer. J: Hum. Genet. 25: 372 (1973)

26. Vidgoff, J., Buist, N. R. M., Miller, A., Tennant, L., and O'Brien, J. S.: Non-uniform distribution of hexosaminidase A (Abstr.). Amer. J. Hum. Genet., 26: 89A (1974).

27. Yabuuchi, H., Sumi, K., Okada, S., and Yutaka, T.: Chromatographic study

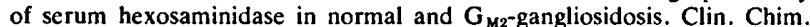
Acta, 53: 85 (1974).

28. Zerfowski, J., and Sandhoff, $K .:$ Juvenile $G_{M_{2}}-$ Gangliosidose mit veränderter Substraspezifität der Hexosaminidase A. Acta Neuropathol., 27: 225 (1974).

29. Gratitude is due to Dr. Y. Fukunishi for the analysis of the rectal biopsy, to Professor R. Okuda for support in this work and to M. Ohara for assistance with the manuscript. We also wish to thank Dr. B. H. Landing, Childrens Hospital, Los Angeles, for pertinent discussion and Drs. S. Okada, Department of Pediatrics, Osaka University Hospital, Osaka, and T. Shimidzu, Department of Hydrocarbon Chemistry, Kyoto University Faculty of Technology, Kyoto, for kind advice.

30. Requests for reprints should be addressed to: T. Momoi, M.D., Department of Pediatrics, School of Medicine, Kyoto University, Sakyo-ku, Kyoto 606 (Japan).

31. Received for publication January 11, 1977.

32. Accepted for publication May 26, 1977. 